\section{Root Pruning and Trunk Scoring Have Limited Effect on Young Bearing Apple Trees}

\author{
Stephen S. Miller \\ U.S. Department of Agriculture, Agricultural Research Service, Appalachian \\ Fruit Research Station, 45 Wiltshire Road, Kearneysville, WV 25430
}

Additional index words. Malus domestica, cultural management, shoot growth, fruit size

\begin{abstract}
To control excessive growth, vigorous 'Smoothee Golden Delicious', ‘Jonagold', 'Empire', and 'Gala' apple (Malus domestica Borkh.) cultivars on Malling 7A (M.7A) rootstock planted at close in-row spacing $(2.5$ or $1.8 \mathrm{~m})$ were mechanically root-pruned (RP), trunk-scored (TS; ringing), or both, annually for 3 to 5 years beginning in the fourth leaf. Trees were grown in a deep, well-drained, fertile soil and supplied with trickle irrigation. RP reduced terminal shoot length in 2 of 5 years on 'Smoothee Golden Delicious'; trunk cross-sectional area (TCSA) was not affected by RP. TS reduced terminal length in 3 years and TCSA in each of 5 years of treatment on 'Smoothee Golden Delicious'. Bloom density was not affected by RP on 'Smoothee Golden Delicious' but was increased by TS in two of the three years measured. RP reduced terminal shoot length in 'Gala', 'Empire', and 'Jonagold' in most years and TCSA in 1993 for all cultivars. TS had no effect on shoot length or TCSA in these three cultivars. Effects of RP and TS on yield and fruit size varied with year and cultivar. In general, the effects of RP and TS were inconsistent and often failed to reduce shoot growth or canopy spread. No practical advantage was recognized from these techniques for young apple trees growing on a fertile site with trickle irrigation.
\end{abstract}

Excessive shoot growth is a major problem for apple trees growing in the mid-Atlantic and southeastern regions of the United States. The problem is compounded when trees are planted at high density (HD), a practice that has become more common in these fruitgrowing areas in recent years. Excessive shoot growth lowers canopy light levels, reduces yields, lowers fruit quality, and increases the cost of dormant pruning and pest control. Lack of effective shoot growth control is one of several hindrances in developing overthe-row mechanical harvesting for apples (Peterson, 1985). Peterson and Miller (1985) found that nonspur apple cultivars were difficult to maintain in a HD system $(\geq 1122$ trees/ ha) without some means for growth control. Loss of the growth regulator butanedioic acid mono(2,2-dimethylhydrazide) (daminozide) and a failure to obtain registration for $\beta-[(4-$ chlorophenyl)methyl]- $\alpha(1,1$-dimethylethyl)1H-1,2,4-triazole-1-ethanol (paclobutrazol) eliminated an effective growth control technique for HD free-standing apple plantings.

Root pruning (RP) is a potential growth control alternative to plant growth regulators (Geisler and Ferree, 1984a). RP reduces growth of young (Ferree and Rhodus, 1993; Schupp

Received for publication 14 Nov. 1994. Accepted for publication 11 Apr. 1995. Mention of a trademark, proprietary product, or vendor does not constitute a guarantee or warranty of the product by the U.S. Dept. of Agriculture and does not imply its approval to the exclusion of other products or vendors that also may be suitable. The cost of publishing this paper was defrayed in part by the payment of page charges. Under postal regulations, this paper therefore must be hereby marked advertisement solely to indicate this fact. and Ferree, 1987; Schupp et al., 1992) and mature (Ferree, 1992; Schupp and Ferree, 1988) field-grown apple trees. The effect on young greenhouse-grown (Geisler and Ferree, 1984b; Schupp and Ferree, 1990) or nonbearing apple trees in the field (Rom, 1982) is less apparent and may not last through the growing season. Trees with a light crop are less affected than similar trees with a heavy crop (Schupp and Ferree, 1987). Apple tree response to RP also varies with time of application (Ferree, 1992; represents the mean of 18 measurement trees. ${ }^{z}$
Schupp and Ferree, 1987) and distance from the trunk (Schupp and Ferree, 1988). Depth of RP had no influence on growth of mature 'Melrose'/M.26 apple trees beyond a 25-cm soil depth (Schupp and Ferree, 1988).

Ringing or scoring the tree trunk is an old technique used to promote flower bud formation and to reduce shoot growth (Tukey, 1964). Trunk scoring (TS) reduced terminal growth on young bearing apple trees (Batjer and Westwood, 1963; Greene and Lord, 1983). It also reduced trunk cross-sectional area (TCSA) terminal growth, shoot diameter, and shoot count on mature trees (Autio and Greene, 1992). Scoring reduced vegetative growth in the year of treatment and the following year in young spur and nonspur 'Delicious' apple trees (Greene and Lord, 1978).

This study was initiated to determine the effect of RP or TS on the growth of young apple trees on M.7A rootstock in closely spaced HD plantings in a typical mid-Atlantic fruitgrowing environment.

Trees were planted $30 \%$ to $60 \%$ closer than the recommended in-row spacing for the cultivar-rootstock combinations used (Adams County Nursery, 1993; Lord and Constante, 1977) to achieve the higher tree densities and early yields desired by the industry.

\section{Materials and Methods}

General. Two studies were conducted: one began in 1988 and a second, on a different group of trees, in 1991. Trees were grown in a Hagerstown/Frederick cherty silt loam (fine, mixed, mesic Typic Hapludalf). The soil was deep and well drained with a high moistureholding capacity and high natural fertility. All trees were trained to a central leader (CL). Trees in the 1988 study were dormant-pruned annually, and branches were spread with liberal use of limb spreaders. Trees in the 1991
Table 1. Effect of root pruning (RP) and trunk scoring (TS) on terminal shoot length and trunk cross-sectional area (TCSA) in young 'Smoothee Golden Delicious'/M.7A apple trees during 5 years. Each value

\begin{tabular}{|c|c|c|c|c|c|}
\hline Treatment $^{y}$ & 1988 & 1989 & 1990 & 1991 & 1992 \\
\hline \multicolumn{6}{|c|}{ Terminal shoot length $(\mathrm{cm})$} \\
\hline \multicolumn{6}{|l|}{ RP } \\
\hline+ & 40.5 & 27.2 & 37.0 & 37.6 & 41.2 \\
\hline- & 46.5 & 29.4 & 40.6 & 41.9 & 47.6 \\
\hline \multicolumn{6}{|l|}{ TS } \\
\hline+ & 39.1 & 26.5 & 38.8 & 36.3 & 43.5 \\
\hline- & 47.8 & 30.1 & 38.9 & 43.3 & 45.3 \\
\hline \multicolumn{6}{|c|}{ Significance $(\mathrm{P})^{x}$} \\
\hline $\mathrm{RP}$ & 0.039 & 0.102 & 0.204 & 0.107 & 0.023 \\
\hline TS & 0.004 & 0.011 & 0.970 & 0.011 & 0.499 \\
\hline \multicolumn{6}{|c|}{$T C S A\left(\mathrm{~cm}^{2}\right)$} \\
\hline RP & & & & & \\
\hline+ & 27.8 & 47.1 & 59.6 & 78.8 & 86.0 \\
\hline - & 28.2 & 47.5 & 61.6 & 77.6 & 91.6 \\
\hline \multicolumn{6}{|l|}{ TS } \\
\hline+ & 24.9 & 42.3 & 56.5 & 67.5 & 82.0 \\
\hline- & 31.1 & 52.3 & 64.8 & 88.9 & 95.6 \\
\hline \multicolumn{6}{|c|}{ Significance $(\mathrm{P})$} \\
\hline RP & 0.851 & 0.866 & 0.487 & 0.738 & 0.308 \\
\hline TS & 0.001 & 0.001 & 0.006 & 0.001 & 0.018 \\
\hline
\end{tabular}

${ }^{2}$ Three-year-old, central leader, trickle-irrigated trees in 1988.

${ }^{y}$ Applied in Spring 1988 about full bloom and each year afterward.

${ }^{x}$ Treatments pooled and data analyzed as a $2 \times 2$ factorial arrangement. No significant interaction detected. 
study had almost no dormant pruning or training during the first two seasons and only minimal pruning and training thereafter to establish the CL and keep the canopy open to light. All cultivars had a nonspur growth habit and were 3 years old when treatments were initiated.

Four treatments were evaluated: $\mathrm{RP}(+\mathrm{RP})$, TS (+TS), RP + TS (+RP+TS), and a nontreated control (-RP-TS). Roots of individual trees were pruned in 1988,1989 , and 1990 to a depth of 45 to $55 \mathrm{~cm}$ with a sharpened subsoiler mounted on a tractor tool bar. Beginning in 1991, a commercial root pruner (Phil Brown Welding Corp., Conklin, Mich.) was used for RP. This subsoiler pruned to a depth of 30 to $35 \mathrm{~cm}$. Roots were pruned at full bloom \pm 14 days. Trunks were scored 10 to 14 days after full bloom as described for the two studies. Trickle irrigation was applied, when indicated by tensiometers, to supplement rain-

Table 2. Effect of root pruning (RP) and trunk scoring (TS) on bloom density (flower clusters per square centimeter branch cross-sectional area) in young 'Smoothee Golden Delicious'/ M.7A apple trees in 1989 to 1991. Each value represents the mean of a single limb on 18 measurement trees.

\begin{tabular}{cccc}
\hline \hline & \multicolumn{3}{c}{ Bloom density } \\
\cline { 2 - 4 } Treatment $^{z}$ & 1989 & 1990 & 1991 \\
\hline RP & 3.4 & 16.3 & 2.9 \\
+ & 5.3 & 14.1 & 2.4 \\
- & & & \\
TS & 3.4 & 18.7 & 3.6 \\
+ & 5.3 & 11.8 & 1.7 \\
- & Significance (P) & \\
& 0.084 & 0.268 & 0.529 \\
RP & 0.090 & 0.001 & 0.008 \\
TS &
\end{tabular}

${ }^{2}$ Applied to 3-year-old, central leader trees beginning in 1988 and each year after about full bloom ${ }^{y}$ Data analyzed as a $2 \times 2$ factorial. No significant interaction detected.

Table 3. Effect of root pruning (RP) and trunk scoring (TS) on terminal shoot length and trunk cross-sectional area (TCSA) in several apple cultivars.

\begin{tabular}{|c|c|c|c|c|c|c|}
\hline \multirow[b]{2}{*}{ Treatment $^{z}$} & \multicolumn{2}{|c|}{ Gala } & \multicolumn{2}{|c|}{ Empire } & \multicolumn{2}{|c|}{ Jonagold } \\
\hline & 1992 & 1993 & 1992 & 1993 & 1992 & 1993 \\
\hline \multicolumn{7}{|c|}{ Terminal shoot length $(\mathrm{cm})$} \\
\hline RP & & & & & & \\
\hline+ & 24.1 & 25.7 & 26.1 & 22.7 & 27.0 & 19.3 \\
\hline - & 36.9 & 32.7 & 43.0 & 40.1 & 39.2 & 28.3 \\
\hline \multicolumn{7}{|l|}{ TS } \\
\hline+ & 28.7 & 31.9 & 32.0 & 30.2 & 30.8 & 21.2 \\
\hline- & 31.2 & 25.9 & 35.1 & 31.0 & 34.7 & 25.7 \\
\hline \multicolumn{7}{|c|}{ Significance $(\mathrm{P})^{y}$} \\
\hline RP & 0.002 & 0.102 & 0.001 & 0.001 & 0.002 & 0.001 \\
\hline TS & 0.492 & 0.162 & 0.380 & 0.555 & 0.449 & 0.091 \\
\hline \multicolumn{7}{|c|}{$T C S A\left(\mathrm{~cm}^{2}\right)$} \\
\hline \multicolumn{7}{|l|}{$\mathrm{RP}$} \\
\hline+ & 44.8 & 55.5 & 35.6 & 43.2 & 58.7 & 68.4 \\
\hline- & 50.4 & 68.6 & 40.4 & 53.2 & 65.1 & 93.2 \\
\hline \multicolumn{7}{|l|}{ TS } \\
\hline+ & 48.9 & 63.5 & 38.8 & 47.6 & 62.5 & 54.7 \\
\hline- & 45.8 & 59.4 & 36.6 & 47.9 & 61.0 & 58.6 \\
\hline \multicolumn{7}{|c|}{ Significance $(\mathrm{P})$} \\
\hline RP & 0.069 & 0.007 & 0.116 & 0.024 & 0.196 & 0.001 \\
\hline TS & 0.321 & 0.332 & 0.346 & 0.976 & 0.653 & 0.952 \\
\hline
\end{tabular}

${ }^{2}$ Applied in 1991 to 3-year-old trees on M.7A rootstock, repeated in 1992 and 1993. Root-pruned at full bloom \pm 14 days; trunk-scored 10 to 14 days after full bloom.

yTreatments pooled and data analyzed as a $2 \times 2$ factorial arrangement. No significant interaction detected. on two sides of the tree in 1991 and 1992 and 45 to $50 \mathrm{~cm}$ from the trunk in 1993. TS was initiated in 1992 and repeated in 1993; it consisted of a single cut through the bark circumscribing the trunk. Trunk circumference and terminal shoot growth were measured in 1992 and 1993. Tree fruit yield, diameter, and weight; flesh firmness; soluble solids concentration (SSC); and starch index were recorded at harvest. Data were subjected to ANOVA with a $2 \times 2$ factorial arrangement.

\section{Results and Discussion}

1988 study. RP reduced terminal shoot length in 'Smoothee Golden Delicious'/M.7A in the first (1988) and last (1992) year of this study (Table $1 ; P \leq 0.05$ ), but it had no effect in the others. Lack of an RP effect on shoot growth during these 3 years is not readily explained, particularly in 1990, when all trees had a heavy crop (mean yield $43.2 \mathrm{~kg} /$ tree), and previous studies showed a greater response on cropped trees (Schupp and Ferree, 1987; Schupp et al., 1992). However, abundant precipitation $(523 \mathrm{~mm})$ during the growing season (April through August) may have negated any effect according to Ferree (1992). TCSA was not affected by RP (Table 1); however, TS reduced TCSA in 1988 and, to varying degrees, in subsequent years so that TS trees had smaller trunk diameters throughout the study. There was no significant RP $\times$ TS interaction for terminal shoot length or TCSA. Canopy width was not affected by any treatment in this study (data not shown). Canopy width exceeded the allotted space $(250 \mathrm{~cm})$ during the sixth growing season (1990). Applying treatments for two more years had no effect on canopy spread. Bloom density was not affected by RP (Table 2). TS trees had a higher bloom density than nonscored (-TS) trees in 1990 and 1991. There was no RP $\times$ TS interaction for bloom density.

In general, treatments in the 1988 study had little practical value and effects were less pronounced than those previously reported (Autio and Greene, 1992; Ferree, 1992; Greene and Lord, 1983; Schupp and Ferree, 1987, 1988; Schupp et al., 1992). Visually, effects of TS or +RP+TS were more evident in the dormant season as shorter shoots and fewer long vegetative shoots, especially in the upper canopy. Actual whole-tree shoot growth measurements did not support field observations of reduced top growth and shoot development. The lack of response to RP might be due to several factors: 1) the RP cut was too far from the trunk to effectively reduce root volume; 2 ) irrigation or using a mechanical tree planter confined the bulk of the root system to the center line of the row, thus reducing the effectiveness of RP; and 3) the deep fertile soils in this area encourage downward rather than lateral root development, especially in conjunction with trickle irrigation. The distance from the trunk for RP cuts was selected to provide a reduction in shoot extension to a more ideal level $(\approx 25$ to $30 \mathrm{~cm})$. In all cases, the distance selected was between the trunk and the drip line of the tree, an area where the 
most roots might be expected. Schupp and Ferree (1988) reduced growth on mature 'Melrose'/M.26 apple trees at $60 \mathrm{~cm}$ and 80 $\mathrm{cm}$ from the trunk but noted a greater effect at the closer distance. Schupp (1989) obtained satisfactory results on 'McIntosh'/MM.111 trees root pruned at $102 \mathrm{~cm}$ from the trunk. If the mechanical tree planter does encourage root growth in the center line of the row, the root pruner may have failed to cut a significant portion of the root system. However, I am not aware of any studies to confirm the hypothesis that mechanical tree planters encourage root development in the center line of the row; previous reports on root pruning have not described the method used to plant test trees. Ferree (1992) showed a consistent reduction in shoot growth with root pruning at a $40-\mathrm{cm}$ depth and $60 \mathrm{~cm}$ from the trunk on mature 'Jonathan'/M.26 in Ohio, except in years when moisture was abundant.

Contrary to what I expected, TS reduced trunk circumference but had a limited effect on terminal shoot growth. The failure of TS to reduce shoot growth is not explained easily. After three annual treatments, I felt that rapid healing of the knife scoring wound may be masking any potential shoot growth response. However, results were the same when a broader spiral cut was made with a hacksaw blade.

1991 study. The only data collected in 1991 were yield and fruit size on 'Gala'. Yield and fruit size from RP trees tended to be less than -RP-TS trees; but differences were not significant $(P \leq 0.05)$ (data not presented). RP reduced terminal shoot length in all three cultivars ('Gala', 'Empire', and 'Jonagold') in 1992 and 1993, except for 'Gala' in 1992. A trend toward reduced terminal growth was evident in 'Gala' (Table 3). TS did not affect terminal shoot length or TCSA in 'Gala', 'Empire', or 'Jonagold' (Table 3) in contrast to the previous study with 'Smoothee Golden Delicious'. There was no RP $\times$ TS interaction for shoot length or TCSA. There was a slight but nonsignificant trend $(P \leq 0.05)$ for RP to reduce TCSA in 1992 in all three cultivars. In contrast, RP reduced TCSA in all three cultivars in 1993. Failure to reduce tree growth consistently was not expected because trees were vigorous and RP and TS cuts were made where effects generally occur (Geisler and Ferree, 1984a; Greene and Lord, 1978, 1983; Schupp and Ferree, 1988).

Yield of 'Jonagold' was reduced by RP in 1992 (Table 4). Yield of 'Empire' was increased by TS in 1993. There were no other effects of RP or TS on yield. In 1992, there was a significant $(P=0.047) \mathrm{RP} \times \mathrm{TS}$ interaction for yield in 'Gala' (Fig. 1, top). TS trees or RP trees had higher mean yields compared to nontreated control (-TS-RP) trees. Mean yields for the combined treatment $(+\mathrm{TS}+\mathrm{RP})$, however, were lower than either treatment alone, suggesting that using both methods may have over-stressed trees in 1992. However, treatment means for yield did not differ statistically due to the large tree-to-tree variability.

$\mathrm{RP}$ decreased fruit diameter in 'Gala' in 1992 and in 'Empire' and 'Jonagold' in 1993 (Table 4). TS reduced 'Gala' fruit diameter in
Table 4. Effect of root pruning (RP) and trunk scoring (TS) on yield and fruit diameter of several apple cultivars.

\begin{tabular}{|c|c|c|c|c|c|c|}
\hline \multirow[b]{2}{*}{ Treatment $^{2}$} & \multicolumn{2}{|c|}{ Gala } & \multicolumn{2}{|c|}{ Empire } & \multicolumn{2}{|c|}{ Jonagold } \\
\hline & 1992 & 1993 & 1992 & 1993 & 1992 & 1993 \\
\hline \multicolumn{7}{|c|}{ Yield (kg/tree) } \\
\hline \multicolumn{7}{|c|}{ 年 } \\
\hline+ & $--y^{y}$ & 36.4 & 28.3 & 29.8 & 50.3 & 59.1 \\
\hline- & --- & 47.1 & 30.0 & 24.1 & 61.2 & 54.1 \\
\hline \multicolumn{7}{|l|}{ TS } \\
\hline+ & --- & 45.1 & 26.3 & 33.6 & 59.3 & 54.7 \\
\hline- & --- & 37.6 & 32.1 & 20.8 & 52.0 & 58.6 \\
\hline \multicolumn{7}{|c|}{ Significance $(\mathrm{P})^{x}$} \\
\hline RP & --- & 0.239 & 0.698 & 0.137 & 0.044 & 0.317 \\
\hline TS & --- & 0.476 & 0.137 & 0.003 & 0.124 & 0.400 \\
\hline \multicolumn{7}{|c|}{ Fruit diameter $(\mathrm{mm})$} \\
\hline $\mathrm{RP}$ & & & & & & \\
\hline+ & 68.5 & 64.8 & 73.5 & 69.2 & $---y$ & 74.3 \\
\hline- & 72.6 & 66.6 & 73.6 & 70.5 & --- & 77.7 \\
\hline \multicolumn{7}{|l|}{ TS } \\
\hline+ & 68.9 & 64.9 & 73.1 & 69.5 & --- & 75.7 \\
\hline- & 71.8 & 66.3 & 74.0 & 70.0 & --- & 76.1 \\
\hline \multicolumn{7}{|c|}{ Significance (P) } \\
\hline RP & 0.001 & 0.073 & 0.967 & 0.038 & --- & 0.001 \\
\hline TS & 0.005 & 0.193 & 0.157 & 0.444 & --- & 0.918 \\
\hline
\end{tabular}

${ }^{2}$ Applied to 3-year-old, central leader trees on M.7A rootstock beginning in 1991 and repeated in 1992 and 1993 at full bloom \pm 14 days.

${ }^{\mathrm{y}}$ Significant $\mathrm{RP} \times \mathrm{TS}$ interaction at $P \leq 0.05$. See Figs. $1 \mathrm{~A}$ and $\mathrm{B}$.

${ }^{x}$ Treatments pooled and data analyzed as a $2 \times 2$-factorial arrangement. Significant interaction shown graphically in Fig. 1.

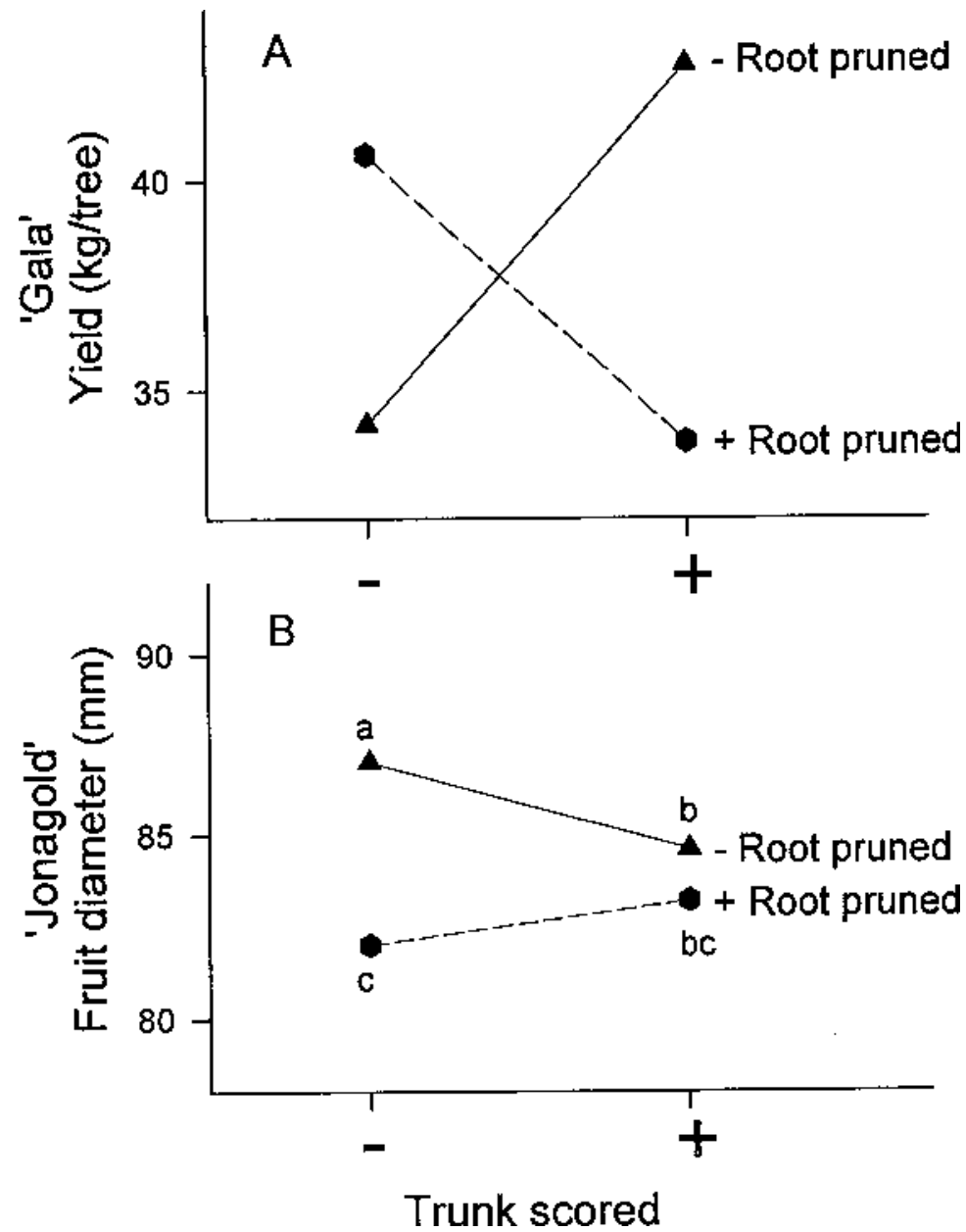

Fig. 1. Interaction of root pruning $(+) \times$ trunk scoring $(+)$ for 'Gala' apple $(\mathbf{A})$ yield and 'Jonagold' apple (B) fruit diameter in 1992. Mean separation by Duncan's multiple range test at $P \leq 0.05$. 
1992 but had no other effect on fruit size in this study. There was a significant $(P=0.019) \mathrm{RP}$ $\times$ TS interaction for fruit diameter in 'Jonagold' in 1992 (Fig. 1, bottom). RP and TS alone reduced 'Jonagold' fruit diameter; however, the effect was not additive. Fruit diameter of $+\mathrm{RP}+\mathrm{TS}$-treated 'Jonagold' was less than that of nontreated (-RP-TS) trees, but the combined treatment did not differ from either treatment alone. Treatments that reduced fruit diameter also reduced fruit weight (data not shown). Previous studies have shown that root pruning reduces fruit size (Ferree, 1992; Schupp and Ferree, 1987, 1988). The small reduction in fruit size ( 3 to $4 \mathrm{~mm}$ ) has practical implication: it represents a reduction of one tray-pack box size. Treatment effects on fruit quality (firmness, SSC, and starch index) were inconsistent; differences, where they existed, were considered to have no practical value (data not presented).

Results from these studies indicate that RP, TS, or both are not universal methods for growth control in HD apple plantings. This finding contrasts with the successes reported elsewhere (Autio and Greene, 1992; Batjer and Westwood, 1963; Ferree and Rhodus, 1993; Green and Lord, 1983; Hull, 1990; Schupp, 1989; Schupp and Ferree, 1988; Veinbrants, 1972). RP was inconsistent and generally failed to reduce shoot growth or slow canopy spread to the extent that no practical advantage was recognized from this technique for young apple trees growing on a fertile site with trickle irrigation. TS reduced shoot length and trunk size in 'Golden Delicious' but had no effect on growth of 'Gala', 'Empire', or 'Jonagold'. I can only speculate that these treatments might have been more effective if trees had not been irrigated and RP cuts had been made closer to the trunk. The lack of response to RP in these studies on apple is similar to that for root restriction studies on peach [Prunus persica $($ L.) Batsch] under similar edaphic and irrigation conditions (D.M. Glenn, personal communication).
Based on these studies, RP or TS cannot be recommended as cultural techniques for growth control in young trees under growing conditions similar to those used in these tests. Proper selection of rootstock-scion combinations and planting distances remain the best known approaches to solve the problem of canopy crowding and excessive vegetative growth. Ferree and Rhodus (1993) arrived at a similar conclusion based on a 10-year study of root-pruned trees in a HD planting. Their results agree with the advice that Schupp (1989) gave after numerous root-pruning studies in several locations. My results suggest that additional studies to examine root development patterns for trees established with a mechanical tree planter, with or without trickle irrigation, may provide valuable information in developing future recommendations.

\section{Literature Cited}

Adams County Nursery. 1993. Fruit tree catalog and grower reference guide. Adams County Nursery, Aspers, $\mathrm{Pa}$.

Autio, W.R. and D.W. Greene. 1992. Ringing and scoring to control growth of apple trees: Results from 1991. Massachusetts Coop. Ext. Serv. Fruit Notes 57(3):1-5.

Batjer, L.P. and M.N. Westwood. 1963. Effects of pruning, nitrogen, and scoring on growth and bearing characteristics of young 'Delicious' apple trees. Proc. Amer. Soc. Hort. Soc. 82:510.

Ferree, D.C. 1992. Time of root pruning influences vegetative growth, fruit size, biennial bearing, and yield of 'Jonathan' apple. J. Amer. Soc. Hort. Sci. 117:198-202.

Ferree, D.C. and W.T. Rhodus. 1993. Apple tree performance with mechanical hedging or root pruning in intensive orchards. J. Amer. Soc. Hort. Sci. 118:707-713.

Geisler, D. and D.C. Ferree. 1984a. Response of plants to root pruning. Hort. Rev. 6:155-188.

Geisler, D. and D.C. Ferree. 1984b. The influence of root pruning on water relations, net photosynthesis, and growth of young 'Golden Delicious' apple trees. J. Amer. Soc. Hort. Sci. 109:827831.
Greene, D.W. and W.J. Lord. 1978. Evaluation of scoring, limb spreading, and growth regulators for increasing flower bud initiation and fruit set on young 'Delicious' apple trees. J. Amer. Soc. Hort. Sci. 103:208-210.

Greene, D.W. and W.J. Lord. 1983. Effects of dormant pruning, summer pruning, scoring, and growth regulators on growth, yield, and fruit quality of 'Delicious' and 'Cortland' apple trees. J. Amer. Soc. Hort. Sci. 108:590-595.

Hull, J. 1990. What have we learned about root pruning fruit trees? Good Fruit Grower 41(7):4 5,45 .

Lord, W.J. and J. Constante. 1977. Establishment and management of compact apple trees. Massachusetts Coop. Ext. Serv. Circ. 102.

Peterson, D.L. 1985. Cultural modifications of deciduous tree fruit for mechanized production. HortScience 20:1015-1018.

Peterson, D.L. and S.S. Miller. 1989. Advances in mechanical harvesting of fresh market quality apples. J. Agr. Eng. Res. 42:43-50.

Rom, R.C. 1982. Pruning apple roots at planting. Ark. Farm Res. July-August:1-5.

Schupp, J. 1989. Root pruning. Intl. Dwarf Fruit Tree Assn. CompactNEWS November:3-4.

Schupp, J.R. and D.C. Ferree. 1987. Effect of root pruning at different growth stages on growth and fruiting of apple trees. HortScience 22:387390.

Schupp, J.R. and D.C. Ferree. 1988. Effects of root pruning at four levels of severity on growth and yield of 'Melrose'/M.26 apple trees. J. Amer. Soc. Hort. Sci. 113:194-198.

Schupp, J.R. and D.C. Ferree. 1990. Influence of time of root pruning on growth, mineral nutrition, net photosynthesis and transpiration of young apple trees. Scientia Hort. 42:299306.

Schupp, J.R., D.C. Ferree, and I.J. Warrington. 1992. Interactions of root pruning and deblossoming on growth, development and yield of 'Golden Delicious' apple. J. Hort. Sci. 67:465480.

Tukey, H.B. 1964. Dwarfed fruit trees. Macmillan, New York.

Veinbrants, N. 1972. Effects of succinic acid-2,2dimethylhydrazide (Alar) or scoring on growth and flower initiation of young apple trees. Austral. J. Expt. Agr. \& Animal Husbandry 12:8995. 